\title{
A VÁLLALATI ELŐRETEKINTÉS HELYZETE ÉS FEJLESZTÉSÉNEK LEHETŐSÉGEI A VISEGRÁDI ORSZÁGOKBAN: EGY V4-ES KÖZÖS KUTATÁS TAPASZTALATAI
}

A tanulmány célja, hogy betekintést nyújtson egy közös jövőalkotási folyamatba, illetve annak eredményeibe, ahol a visegrádi országok képviselői - jövőkutatók és gyakorló vállalatvezetők - működtek együtt. A kutatási projekt keretében a résztvevők alternatív gazdasági forgatókönyveket dolgoztak ki az érintett országok vállalatai számára, hangsúlyozva azt, hogy a forgatókönyvírás tanulható és hasznosítható a vállalati stratégiaalkotásában, valamint elősegítheti a vállalati előretekintés széles körű elterjedését e térségben. A közös munka során született eredmények egy részéről számol be ez a tanulmány, amely betekintést nyújt egy jövőalkotó technika tanulási folyamatába a gyakorlatban, illetve a nemzetközi együttműködés során létrejött releváns és előremutató gazdasági forgatókönyvek tartalmába.

\section{Kulcsszavak: vállalati előretekintés (foresight), visegrádi országok (V4), forgatókönyv-elemzés}

A „Vállalati foresight (előretekintés) lehetőségei a visegrádi országokban (V4) / „Corporate Foresight Potential in Visegrad countries" címü FOR V4 projekt röviden V4-es projekt - 2016-ban zajlott, melynek tagjaiként egy közös kutatási folyamatban vettünk részt. Ennek során helyzetfeltáró országtanulmányokat készítettek az egyes országok kutatási programba bevont jövőkutatói és gyakorló vállalatvezetői, majd közös jövőalkotó műhelymunkában vettek részt. Ennek a közös alkotási folyamatnak, a magyar kutatók által összefoglalt eredményeiről számol be ez a tanulmány. A V4-es projekt egyik célja az volt, hogy az érintett országokból érkező gazdasági szereplöknek bemutassa a közös jövőalkotási folyamatban rejlő hasznokat, a reflexión és vízión alapuló vállalati jövőalkotást, amely támogatja a V4-es régió hosszú távú alkalmazkodó képességének fejlesztését. A projekt másik célja az volt, hogy előmozdítsa az elöretekintés (foresight) eszköztárának használatát a V4-es országok vállalkozóinak gyakorlatában, amely mozgatórugója lehet a vállalati kultúrának, és erősítheti a V4-es országok gazdasági közösségének hangját az Európai Unióban és más szervezetekben. ${ }^{1}$

A lengyel kutatóközpont (The Institute for Sustainable Technologies - National Research Institute (ITeE-PIB)) irányításával létrejött kutatási projekt cseh, szlovák és magyar kollégákkal közösen megfogalmazott feladatai közül kettőt emelünk ki: a) a nemzeti előretekintési gyakorlatok összegyüjtése és elemzése, b) egységes módszertani irányok kialakítása a vállalati előretekintési kultúra és azon keresztül a régió gazdasági fejlődésének érdekében. A közösen meghatározott feladatok első lépéseként öszszegyűjtöttük a nemzeti szinten is fellelhető elöretekintési gyakorlatokat az egyes részt vevő országokban, amelynek rövid összefoglalását és összevetését tartalmazza az 1 . táblázat.
A visegrádi országokban nincs széles körű gyakorlata a vállalati előretekintési programok alkalmazásának. A magyarországi előretekintési gyakorlatról korábbi cikkünkben (Hideg et al., 2017) már beszámoltunk, ahol a hazai vállalati elöretekintés alkalmazásainak konkrét példáit is bemutattuk, rávilágítva a kis- és középvállalatokban (KKV) rejlö lehetőségekre (Hideg \& Nováky, 2010; Hideg, Nováky, \& Alács, 2014; Gáspár, 2015). Magyarországon korábban is zajlottak makro- és ágazati szintű előretekintési programok, amelyek a technológiai fejlődésre és a szakképzés fejlesztésére irányultak. A technológiai fókuszú elöretekintési program, amit Havas Attila vezetett, úttörőnek számított a régióban mind a széles érintetti kör bevonására építő és részvételével zajló munkacsoportok, mind a tartalmi sokszínüség és gazdagság terén (Havas, 2003). Ezen kívül egy ágazati előretekintési programsorozat is folyt a hazai szakképzés jövőjéről az 1990-es és a 2000-es években, amelyeket Hideg Éva és Nováky Erzsébet vezettek, és amely úgyszintén bekerült a nemzetközi jó gyakorlatok közé (Hideg, Nováky, \& Kristóf, 2013). Noha a programokban gazdasági szereplők is részt vettek, a vállalati előretekintési tevékenység nem vált jelentőssé hazánkban.

Nemzeti elöretekintési programokat a V4-es régió minden országában készítettek. A programok az ENSZ Iparfejlesztési Szervezete (angolul: United Nations Industrial Development Organization, UNIDO) által támogatott Nemzeti Előretekintési Programleírást követték, mely szerint a bevont szakértők és gyakorló vállalatvezetők eltérő munkacsoportokban, egy Delphi kérdőívekkel történő szakértői lekérdezés után, regionális fejlődési irányokat határoznak meg. A hosszabb távú gondolkodás, a tudatos jövőalkotás kezdett ugyan beszivárogni a vállalati gyakorlatba, de a nagyvállalatok kivételével nem vált általánosan alkalmazott döntés-elökészítő, illetve döntéstá-

\footnotetext{
A kutatási célokról további információ a részt vevő országok saját nyelvén a projekt honlapján olvasható: http://www.visegradforesight.itee.radom.pl/ index.php/hu/
} 
mogató eszközzé a V4-es országokban. A KKV-k szintjét tekintve egyes országokban a jövőorientált gondolkodás és az elöretekintési eszközök stratégiai menedzsmentbe ágyazottságát emelték ki a kutatók (Csehország, Magyarország) (Valenta, 2014; Gáspár, 2015). Máshol pedig a vállalati, iparági innovációs folyamatok fontos elemeként említették (Lengyelország, Szlovákia) (Daszkiewicz, 2014; Nemcová, 2013) a vállalati elöretekintési tevékenységeket. Összességében megállapítható, hogy a V4-es országokban a vállalati stratégiaalkotásba beágyazódott, a vállalati kultúra részét képezö, vagy akár intézményesült jövőalkotó módszereknek számottevő elterjedtsége nem mutatható ki. Ezért is tekinthető jelentős eredménynek e kutatásban elindított regionális együttgondolkodás, a közös jövőalkotás, valamint az egyes konkrét módszerek és eszközök gyakorlati alkalmazásának megtapasztalása.

A V4-es országok vállalatai esetében a külső szakértők által készített előrejelzések figyelemmel kísérése és felhasználása, valamint a saját, vállalati adatbázisok alapján készített előreszámítások képezik a leggyakrabban müvelt önálló vállalati előrejelzési gyakorlatot. A vállalati előretekintést illetően pedig a vállalatvezetők feladata a vállalat víziójának és küldetésének meghatározása. Ehhez azonban nem vesznek igénybe az elöretekintési irodalomban kifejlesztett módszereket és eljárásokat, hanem saját tapasztalataikra és elképzeléseikre támaszkodnak (Jannek \& Burmeister, 2007; Kononiuk \& Glinska, 2015). Természetesen a multinacionális leányvállalatok az anyavállalatukhoz kapcsolódnak e téren is. Ezt a helyzetet alapul véve döntött úgy a kutatóközösség, hogy önkéntesen jelentkező és érdeklődő vállalkozóknak egy igen egyszerü, de hatékony előretekintő eljárást, a forgatókönyvírást tanítsa meg egy workshop keretében. Ezzel az eljárással nemcsak a jövőalternatívákban gondolkodás szisztematikus módja sajátítható el, hanem a vállalati jövőformáló gyakorlat egy egyszerü és hatékony formájának kialakítása is. ${ }^{2}$ A kutatócsoport ezért a stakeholderek vagy érintettek részvételével müködő és kölcsönös tanulási folyamatot generáló forgatókönyvírást választotta a tanítás-tanulás tárgyává.

\section{A forgatókönyvírás tanulása}

Az egyes országok előretekintési gyakorlatának áttekintése után a projekt arra összpontosított, hogy a kutatásban részt vevő, különböző országokból érkező vállalati szakembereket megtanítsa egy mühelymunka keretében a vállalati elöretekintés egyik legnépszerübb és legsokoldalúbban

1. táblázat A vállalati előretekintés gyakorlata a V4 országaiban

\begin{tabular}{|c|c|c|c|}
\hline & $\begin{array}{c}\text { Makroszintü előretekintő } \\
\text { tevékenység }\end{array}$ & $\begin{array}{c}\text { Vállalati előretekintés } \\
\text { jellemzője }\end{array}$ & $\begin{array}{c}\text { Vállalati elöretekintés } \\
\text { megjelenése }\end{array}$ \\
\hline Csehország & $\begin{array}{l}\text { Nemzeti Kutatási Program I. II. } \\
\text { III. (2001 - 2012) } \\
\text { Stratégiai Keretprogram } \\
\text { a Fenntartható Fejlődésért - } \\
\text { Csehország } 2030 \text { (2015) }\end{array}$ & $\begin{array}{l}\text { Eszközei/szemlélete beépül } \\
\text { a stratégiai tervezés és } \\
\text { a stratégiai menedzsment } \\
\text { folyamataiba. }\end{array}$ & $\begin{array}{l}\text { Közepes és nagyvállalatoknál } \\
\text { (energia, elektronika, } \\
\text { gyógyszeripar) technológiai } \\
\text { fejlesztési és együttműködési } \\
\text { céllal - iparági alapon } \\
\text { szerveződnek. }\end{array}$ \\
\hline Lengyelország & $\begin{array}{l}\text { Nemzeti Előretekintési Program - } \\
\text { Lengyelország 2020; } \\
\text { Technológiai Előretekintés, } \\
\text { Iparági be- és elöretekintés - } 2030 \\
\text { (Gazdasági Minisztérium) }\end{array}$ & $\begin{array}{l}\text { Elmaradottabb régiókban } \\
\text { a túlélés, a fennmaradás } \\
\text { kérdései hatják át a rövid távú } \\
\text { gondolkodást. }\end{array}$ & $\begin{array}{l}\text { Regionális előretekintési } \\
\text { programok, termék- és } \\
\text { folyamatinnováció egyes } \\
\text { KKV-nál, illetve az ellátási } \\
\text { láncok mentén szerveződik. }\end{array}$ \\
\hline Magyarország & $\begin{array}{l}\text { A szakképzés jövője } \\
\text { (1990-es évektől 2007-ig) } \\
\text { Technológiai Előretekintési } \\
\text { Program (2000) } \\
\text { Magyarország } 2025 \text { (2008-2010 } \\
\text { MTA Jövőkutatási Bizottság) }\end{array}$ & $\begin{array}{l}\text { A KKV-szektorban a túlélés } \\
\text { mellett a rövid távú szemlélet } \\
\text { dominál; az előretekintő } \\
\text { technikák alkalmazása } \\
\text { nagyvállalatokra jellemző. }\end{array}$ & $\begin{array}{l}\text { Regionális elöretekintési } \\
\text { programok - KKV-k } \\
\text { a közép-magyarországi régióban } \\
\text { - földrajzi alapon szerveződő } \\
\text { együttmúködések. }\end{array}$ \\
\hline Szlovákia & $\begin{array}{l}\text { A „Szlovákiai fejlődés víziója” } \\
2020 \text { - a Szlovák Tudományos } \\
\text { Akadémia és Szlovákiai és Világ } \\
\text { Gazdasági Intézet (SAV) } \\
\text { együttmüködésében; Technológiai } \\
\text { Előretekintési Program } \\
\text { (2006-2015) }\end{array}$ & $\begin{array}{l}\text { Tudásalapú-gazdaság } \\
\text { támogatásának eszköze; } \\
\text { az előretekintés típusú } \\
\text { vállalati tevékenységek } \\
\text { elösegítése. }\end{array}$ & $\begin{array}{l}\text { Országos és önkormányzati } \\
\text { szinten jelenik meg } \\
\text { az elöretekintés és ebbe lépnek be } \\
\text { érintettként a vállalatok. }\end{array}$ \\
\hline
\end{tabular}

Forrás: Corporate Foresight Potential in Visegrad (V4) Countries (2016), 23-75. old. alapján

\footnotetext{
${ }^{2}$ A szakirodalomban és a vállalati gyakorlatban is, többféle eljárása létezik a forgatókönyvírásnak. Ezek rendszerező áttekintését lásd például Godet (2000) és Bradfield et al. (2005) irodalmakban.
} 
hasznosítható eljárására, az érintettek részvételével folyó forgatókönyvírásra (Glann \& Gordon, 2009). Tette mindezt azzal a céllal és várakozással, hogy a tanulási folyamat során elsajátított eljárást a vállalatvezetők képesek legyen továbbéltetni és terjeszteni hazai szűkebb környezetükben is. A gyakorlati tapasztalatot felhasználó tanítás és tanulás módszere az együttmüködésre és dialógusra épülö csinálva tanulás (Borch, 2013; Borch \& Mérida, 2013; Kristóf, 2013) volt, amelyben a jövőkutatási szakértők, mint facilitátorok, és a különböző területeken dolgozó V4-es országok vállalatainak felső és középvezetői vettek részt és alkották meg közösen a különböző forgatókönyveket. A saját vállalati menedzsmenttel és stratégiaalkotó gyakorlattal rendelkező szakemberek egy kétnapos mühelymunka keretében tanulták meg az intuitív logikán alapuló és népszerü kétdimenziós forgatókönyvírást (Fahey \& Randall, 1998). A tanulási folyamat három szakértői csoportban zajlott. A négy-öt fös csoportok mindegyike a különböző országból érkezett vállalati stratégából és egy-két, szintén különböző országból érkezett jövőkutató facilitátorból állt. A tanulók a csoporttagok voltak, a tanítók pedig az egyes munkafázisokat bemutató előadók és a csoportokhoz kapcsolódó facilitátorok. A facilitátorok felügyelték és támogatták a csoportokat az egymásra épülő munkafázisok feladatainak megoldásában. A facilitátorok munkafázisok szerint cserélődtek, hogy ne befolyásolják jelentősen egy-egy csoport önálló és érdemi munkáját. Az egymást követő munkafázisokat az 1. folyamatábra mutatja.

\section{1. folyamatábra A forgatókönyvek kialakításának folyamata - A munkafázisok}

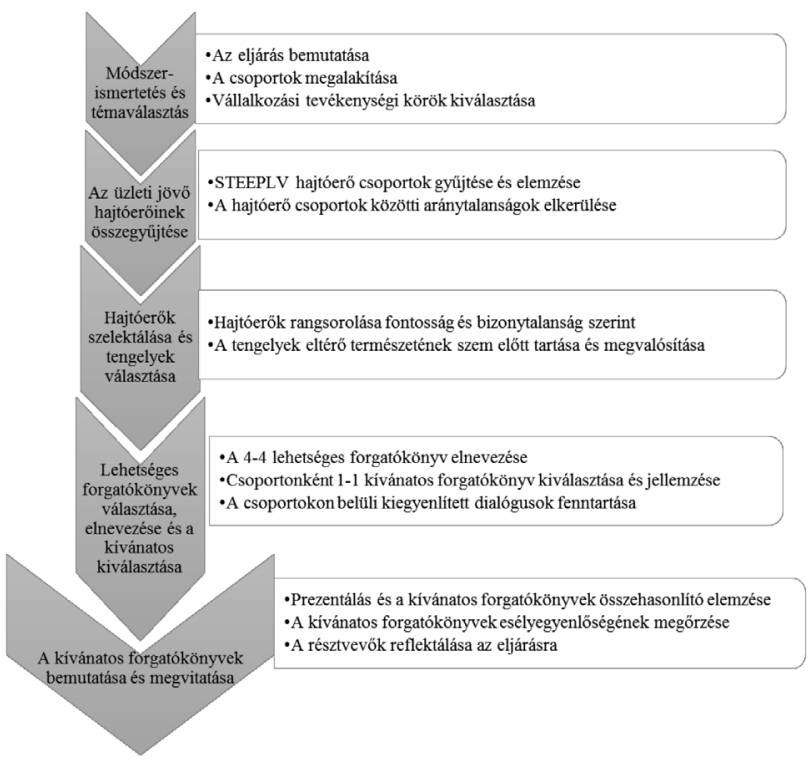

Forrás: saját szerkesztés
Az általános bemutatkozás után a csoport a bevezető előadásban felvezetett első munkafázison dolgozott, melynek első feladataként minden csoport választott magának egy konkrét üzleti területen tevékenykedő vállalatot, melynek nevet is adott. Erre azért volt szükség, hogy a csoportok az általuk legjobban ismert területre fókuszáljanak és a tapasztalataikra és ismereteikre épitkezve elképzeljék, milyen külsö és belsö változásokat elöidézö tényezökkel lehet számolni a jövöben a választott és elgondolt vállalat életében. A csoportok az alábbi vállalkozásokat jelölték meg a forgatókönyvek tárgyául:

$>\mathrm{Az}$ 1. csoport a gépgyártás területét választotta, és a vállalata neve „Gépipari Vállalat“ lett. A vállalat Csehországban müködik és 200 főt foglalkoztató helyi KKV.

$>$ A 2. csoport a közösségi közlekedést, szállítást, logisztikát, az ellátásilánc-menedzsmentet és hírközlést választotta, így vállalatának neve „Logisztikai központ a V4-ek régiójában" "lett ${ }^{3}$. Ez a vállalat a régióban több különböző helyen üzemelő, egységben müködő globális, nemzetközi vállalkozás, amely szervezi a személyek, áruk, információk áramlását.

> A 3. csoport a 3D-s csúcstechnológiára szerveződő és „3D-s Nyomtató Társaság“ nevü, 50 föt foglalkoztató KKV-t választotta, mely cég telephelye Dél-Lengyelországban van, globális és internacionális formában működik, és a nyomtatási szoftverek fejlesztésére szakosodott szolgáltató vállalkozás. A résztvevők szerint a hardver témát már más térségek és gyártók lefoglalták, szabad üzleti lehetőség a szoftverfejlesztés terén áll még rendelkezésre.

\section{A hajtóerők összegyűjtése és elemzése ${ }^{4}$}

A következő munkafázis a változásokat kiváltó hajtóerök összegyüjtése volt, követve a szakirodalom által javasolt STEEPLV (Society, Technology, Ecology, Economy Policy, Legal, Value /társadalmi, technológiai, gazdasági, politikai, jogi, értékalapú) csoportosítás logikáját (Rohrbeck, Arnold \& Heuer, 2007). E feladat lényege, hogy a vállalat jövőjére várhatóan hatást gyakorló különféle külső és belső tényezőket rendszerezett formában tárja fel és gyüjtse össze. A csoportmunkák során a facilitátorok azt felügyelték, hogy mindegyik szempont megjelenjen, illetve pozitív és negatív változásokat egyaránt tartalmazzon a ,készlet”.

A „Gépipari vállalat” csoport STEEPVL elemzéshez gyüjtött hajtóerői között a társadalmi tényezőkre vonatkozó hajtóerők két témakörre koncentráltak. Az egyik a képzett és jó képességekkel rendelkező munkaerő iránti igény növekedése, a másik pedig a hosszabb élettartam miatti egészség, képességek, tudás és közösségi létformák folya-

\footnotetext{
${ }^{3}$ Érdekes egybeesés, hogy „Magyarország, mint logisztikai központ” koncepció már a 2000 évek eleje óta foglalkoztatja a Chikán Attila vezette kutatókból és vállalatvezetőkből álló közösséget, akik a koncepció kidolgozásakor regionális „,roadshow”-k keretében az akadémiai és az állami szféra (Ipari kamara) képviselőivel közösen ,járták az országot”, hogy a szervezett fórumokon vállalatvezetőkkel vitassák meg a koncepció lehetséges előnyeit és hátrányait. A közel két hónapos program elöretekintés szempontú elemzéséről részletesebben lásd Balogh \& Zimonyi (2006) tanulmányát.

${ }^{4}$ A csoportonkénti hajtóerők rövid felsorolását lásd Corporate Foresight Potential in Visegrad (V4) Countries (2016), 109-112. old.
} 
matos „karbantartási igényének” növekedése volt. A képességek és a képzettség növekedése pozitív hajtóerőnek minősült, de ugyanakkor felmerült annak hátránya, hogy ezek a követelmények leginkább a jelenleg nagyszámú, de egyre korosodó munkavállalók körében érhetők tetten. Az életkor várható meghosszabbodása ezen túlmenően pozitív vonatkozásokat is felszínre hozott. Ilyenek voltak a csoportos együttműködés iránti hajlandóság erősödése, a felelősség a saját életért és karrierért, valamint az egész életen át tartó tanulásért. Az életkor várható hosszabbodása ugyanakkor veszélyes is lehet, mert konzerválhatja a rutint és erősítheti a munkatársak szellemi képességeinek gyengülését.

A technológiai hajtóerök közül várhatóan pozitív hatásúnak tekintették a csoporttagok az energiatárolás javulását, az új anyagok megjelenését a 4.0 iparosítást, a logisztikai láncok, a kommunikáció informatikai alapú szervezését, a know-how bővülését, a digitalizációt, a virtuális és a kiber modellek, a mesterséges intelligencia, a gépi tanulás alkalmazását, az osztott $\mathrm{K}+\mathrm{F}$ és a nyitott innováció terjedését. Negatív hatásra viszont csak kisebb mértékben számítottak: úgy, mint az adatbiztonság kockázatai, a függés az információs és kommunikációs technológiáktól (IKT) és a müszaki szakemberek hiánya.

Az ökológiai tényezők többségét: az ISO szabványt, az ökocímkézést, a körforgásos müködési módra való áttérést, vagy az újrahasznosítást és az energetikai hatékonyság növekedését pozitív kontextusban említették. Ugyanakkor a vízkérdést, a katasztrófák lehetőségének gyakoriságát, az újabb környezeti adókat, a nagy multinacionális cégek szerepének növekedését a természeti környezet és a környezetérzékeny vállalati müködés szempontjából is kedvezőtlen jövőlehetőségnek tekintették.

A számos gazdasági hajtóerő többségét negatív jövőformáló hatásként említették. Ilyenek voltak az embargók és a válságok hirtelen fellépése, a BREXIT vagy a GREXIT lehetősége, ami miatt az EU és az EUR válságba süllyedhet, továbbá a túl sok monetáris és fiskális politikai megszorítás és a közkiadások növekedése. Nagy vitát kiváltó tényezők lettek a fintech, a migráció és a szakemberhiány terjedése, valamint az ipar háttérbe szorulása a szolgáltatások javára.

A politikai tényezők többségét a fejlődést gátló vagy bizonytalanná tevő tényezőkként értékelték. Ilyenek voltak a kulturális különbözőségekhez adaptálódás kényszere, a politikai és a döntéshozási kultúrák közötti eltérések, a rövid távú politikai gondolkodásból és a választási ciklusokból adódó váratlan helyzetek. Egyedül a K+F-nek és a támogatások rendszerének tulajdonítottak pozitív hatást.

Jogi téren is szintén a tiszta, egyértelmü és következetes szabályozás kialakulásában bíztak a gazdasági tevékenységek eredményességét illetően. Negatív változásokat hordozó tényezőnek az adatbiztonság szabályozatlanságát és általában a szükséges szabályozók lassú kidolgozását tekintették.

A társadalmi és az egyéni értékek változását tárgyalva a csoporttagok döntő többségében pozitív értékeket említettek, mint pl. partnerség, szeretet, megbecsülés, humanitás, közös célok követését, a lojalitás, a józan megfontoltság és a nyitott gondolkodásmód terjedését.
A ,Logisztikai központ a V4-ek régiójában” csoport STEEPVL elemzéshez gyüjtött hajtóerőinél a társadalmi tényezők között szinte csak pozitív várakozásokat találunk. Ilyenek voltak: az életkor emelkedése, a társadalmi elvárások növekedése a jobb, pontosabb, $\mathrm{CO} 2$ kibocsátást csökkentő, élvezetet nyújtó, az emberek közötti kapcsolatteremtést segító áruk, termékek és szolgáltatások irányba, valamint az emberek helyváltoztatását támogató különféle szolgáltatások összehangolása. Nem egyértelmüen pozitív társadalmi tényezőként merültek fel az egyes térségek népességnövekedése és az annak révén egyre növekvő utazási és szállítási igények, valamint az azokat követni és kiszolgálni képes logisztikai kapacitások biztosítása.

A technikai-technológiai tényezők között egyaránt előfordultak e szolgáltatás mennyiségét és minőségét javító tényezők, valamint azok telepítésével, társadalmi igény szerinti müködtetésével kapcsolatos elvárások. Ilyenek voltak az integrált szolgáltatásnyújtás feltételeinek kielégítése informatikai megoldásokkal, infrastrukturális hálózatok kiépítésével és müködtetésével, a mesterséges intelligencia használata, az útvonaltervezés, az önjáró autó, a megosztott jármühasználat, a dugók kiküszöbölése, új anyagok, üzemanyagok használata, szoros együttmüködés a várostervezéssel. Várható negatív hatást kiváltó tényezők egyáltalán nem merültek fel ennél a csoportnál azt feltételezve, hogy a technika majd mindent meg tud és fog oldani.

Az ökológiai hatások jelentősen polarizáltak voltak. A csoport szerint a biztonságos forgalom mellett majd csökken a $\mathrm{CO}_{2}$ kibocsátás, a visszaforgatás hatására a hulladék mennyisége is csökken, az üzemanyagok felhasználása is visszaesik. A szektor környezeti hatásai rendkívül érzékenyen érintik az ökoszisztémákat, ezért az államnak/régiónak is támogatnia kell majd a környezetbarát közlekedést és azon belül az e-megoldásokat.

A gazdasági hajtóerőknél is a pozitív várakozások domináltak még akkor is, ha azok jövőben megoldandó problémákat jeleznek elöre. Ilyen volt a régiós logisztikai rendszer vegyes finanszírozásúvá alakítása, a gazdaságos üzemméret biztosítása, a folyamatosan csökkenő tarifák melletti költségcsökkentés és versenyképesség fenntartá$\mathrm{sa}, \mathrm{az}$ adózás régiós rendszerének kialakítása. E várakozások megvalósulásában az üzemanyagárak kulcsszerepet fognak játszani a csoport szerint.

A politikai tényezők között elsőként szerepelt a V4-es régió államainak elköteleződése a régiós rendszerépítés és müködtetés mellett, amelyet az EU-szabályok is elösegíthetnének. További pozitív hajtóerőt jelenthetnek az érintett nemzetek politikai stabilitása, adó- és jogszabályi összehangolásra törekvése. Negatív és nagy bizonytalanságú tényezőnek tekintették e csoport tagjai a korrupció és a bürokrácia elburjánzását, illetve az azok elleni sikeres küzdelmet.

A jogi témakörben a legfontosabb hajtóerők a vállalati müködési engedélyek, az egységes tarifarendszer, a forgalmi szabályok és az ellenőrzés, valamint a rendszer müködési feltételeit összehangoló jogszabályok kialakítása lettek.

A társadalmi értékek tekintetében a társadalmi felelősségvállalást, a megbízhatóságot, a korlátlan elérhetőséget, 
a biztonságot és a minőségi szolgáltatásokat emelték ki. Ha ezek az értékek nem valósulnak meg, akkor a regionális logisztikai rendszer nem tud hatékonyan és versenyképesen müködni.

A ,,3D-s Nyomtató Társaság” csoport STEEPVL elemzéshez összegyüjtött hajtóerők társadalmi tényezői között a csoporttagok olyanokat említettek, amelyek az új technika iránt támasztott igényt gerjesztik. Véleményük szerint a kreatív szektorok, fóként az életkor növekedésével együtt fejlődő egészségügy, a családi élet atomizálódására, a divat és az új anyagokra fogékony kreatív iparágak igénye hívja majd életre ezt a fajta új technikát. Annak müködtetésére viszont majd a fiatal és képzett informatikusok lesznek képesek, akik iránt növekvő lesz az igény a V4-es térségben.

A technológiai hajtóerőknek óriási szerepük lesz a csoport szerint. A polimerek, a fémek anyagtechnológiája, a biotechnológia új anyagigénye különösen gyorsan változik és fejlődik. Ezekre az új technológiákra a felhasználóközpontúság és az interaktivitás lesz a jellemző, ami miatt a humán tőke is jelentősen megváltozik a jelenlegihez képest. Ugyanakkor fekete dobozként is kell tekinteni a technológiára, mert még rövid távon sem látható előre az újdonságot generáló képessége.

Az ökológiai hajtóerők minden tekintetben a zöldülés és a környezetkímélet felé viszik majd el a fejlödést. Számítani kell a zöld adók, a környezetbarát habitus terjedésére, a $\mathrm{CO}_{2}$ kibocsátás csökkentésére, a megújuló energiák használatának a terjedésére. E tekintetben a 3D-s nyomtatás ideális technológia lesz, ha az elterjed a V4-es országokban.

A gazdasági hajtóerőknél egyrészt számítani lehet a nyersanyagok és a technológiák drágulására, a költségek emelkedésére, a kamatlábak emelkedésére és a protekcionizmusra egyes államok esetén, de olyan ellenhatások megjelenésére is, amelyek az említett gazdasági hajtóeröket erőteljesen enyhíthetik. Ilyen tényezők lehetnek a globalizáció lassulása, a pénzügyi folyamatok technikai fejlődése, a schengeni határvédelem erősödése és a technikai fejlődés általános gyorsulása.

A politikai hajtóerők a maguk ellentmondásos mivoltukban kerültek be a hatóerők sorába. Felmerült pl. az USA-val folytatandó háború, a BREXIT, egy III. világháború lehetősége, egy új kommunista hullám elöretörése, de ugyanakkor pozitív politikai hatások is megjelentek. Erösödhet majd a lobbi tevékenység és az integrációs folyamatok, a közvélemény és a média politikaformáló ereje, vagy a nemzeti fejlesztési stratégiák szerepe a jövő formálásában.

Jogi hajtóerőknél a csoport véleménye a világkormányzástól a szervezett bünözésig terjedt. Ezek közül fóként a fogyasztók és a technika fejlesztését és használatát segítő jogi és nemzetközi szabályozást tekintették fontosnak. Negatív tényezőként tekintettek a szervezett bünözésre, a jogi huzavonákra, a nagyon és a tartósan eltérő nemzeti szabályozásokra.

Az értékeknél ez a csoport arra számít, hogy az új technikákba vetett hit erősödhet, ami elősegítheti a biotechnológiák, az anyagtudományok gyorsabb fejlődését akkor, ha azok gazdaságosan, felelősen és környezetkímélően felhasználhatók lesznek. Ha viszont a profitérdek el- nyomja az erkölcsi értékeket vagy a vallási hatások technikaellenesen erősödnek fel, akkor azok jelentősen lassítják majd a technológiai fejlődést.

Összegezve a termelésben, a szolgáltatásban és a 3D-s csúcstechnológiában jeleskedő vállalatok életére ható, alábbi összetételü változásokat gyüjtötték össze a munkacsoportok (lásd a 2. táblázatot).

\section{2. táblázat A STEEPLV hatótényezők megoszlása} a három vállalat esetében

\begin{tabular}{|l|c|c|c|c|}
\hline $\begin{array}{l}\text { STEEPLV } \\
\text { hatóténye- } \\
\text { zők (db) }\end{array}$ & $\begin{array}{c}\text { (1) „Gép- } \\
\text { ipari } \\
\text { Vállalat” }\end{array}$ & $\begin{array}{c}\text { (2), „Lo- } \\
\text { gisztikai } \\
\text { központ” }\end{array}$ & $\begin{array}{c}\text { (3),3D-s } \\
\text { Nyom- } \\
\text { tató } \\
\text { Társaság” }\end{array}$ & $\begin{array}{c}\text { Össze- } \\
\text { sen }\end{array}$ \\
\hline Társadalmi & 8 & 13 & 4 & 25 \\
\hline $\begin{array}{l}\text { Technoló- } \\
\text { giai }\end{array}$ & 18 & 20 & 7 & 45 \\
\hline Ökológiai & 17 & 8 & 7 & 32 \\
\hline Gazdasági & 19 & 11 & 10 & 40 \\
\hline Politikai & 9 & 7 & 11 & 27 \\
\hline Jogi & 10 & 7 & 11 & 28 \\
\hline $\begin{array}{l}\text { Társadalmi } \\
\text { értékek }\end{array}$ & 11 & 5 & 9 & 25 \\
\hline Összesen & 92 & 71 & 59 & 222 \\
\hline
\end{tabular}

Forrás: Corporate Foresight Potential in Visegrad (V4) Countries (2016), 109-112. old.

Függelék 1., 2. és 3. táblázatai alapján

Az 1. csoport gyüjtötte össze a legtöbb hatótényezőt, míg a 3. közel egyharmaddal kevesebbet. A mennyiségnél fontosabb, hogy az egyes csoportok milyen összetételben gyüjtötték össze a hatótényezőket. A „Gépipari Vállalat” esetében a gazdasági, technológiai és az ökológiai hatótényezők voltak a legfontosabbak és közel azonos mértékben. A „Logisztikai központ a V4-ek régiójában“ a technológiai hatótényezők szerepe lett kimagasló, és azután pedig a társadalmi és a gazdasági hatótényezők következtek fontossági sorrendben. A ,3D-s Nyomtató Társaság“ esetében a politikai, a jogi, a gazdasági és a társadalmi értékek körébe tartozó hatótényezők lettek a legfontosabbak, de kisebb mértékben a többi hatótényező is közel egyforma fontosságot mutatott. A hatótényezők belső arányaiból arra lehet következtetni, hogy az egyes csoportok milyen társadalmi szerepet szánnak választott cégüknek a jövőben, illetve, hogy az szerintük milyen környezetben fog majd müködni. A későbbi munkafázisokban mindezt explicit módon is kifejezik az egyes csoportok, amikor a hatótényezőkből tengelyeket választanak, és a 4-4 forgatókönyvüket meghatározzák. Összességében a STEEPLV hatótényezők közül a technológiai, a gazdasági és az ökológiai hatótényezők a leghangsúlyosabbak mindhárom csoport esetében. A többi hatótényező is fontos, de jelentősen kisebb mértékben.

\section{A hajtóerők szelektálása és forgatókönyv-tengelyekké alakítása}

A hajtóerők felvetését és típusokba sorolását egy rövid értelmezési vita követte minden csoportban. Majd, 
amikor már kifogytak a csoportok a hajtóerőkből, következett azok rangsorolása. A rangsorolás szempontja az volt, hogy azok a hajtóerők kerüljenek az egyes hajtóerőtípusok élére, amelyek egyaránt képesek jelentős, de magas bizonytalanságú jövőt formáló pozitív és negatív változásokat kiváltani a csoportok elképzelt vállalata életében. A szakirodalom ezt a hajtóerők hatáserőssége és bizonytalansága szerinti rendezésként említi (Ringland, 2010). A csoportok is ilyen tartalmú eligazítást kaptak, de a sok hajtóerő által mozgósított sokféle lehetőség gondolata megnehezítette számukra azok értékelését és rangsorolását. „A jövő kinyitása” után most már ,a jövő keretek közé szorítására" történő áttérésre egyszerü rangsorolásos módszert alkalmaztunk az idő rövidsége miatt.

A fontossági sorrendet először az egyes hajtóerő típusokon belül állapították meg a csoportok tagjai, majd a típusonkénti csoportelsőket rangsorolták annak érdekében, hogy azokból elvileg két különböző, negatív és pozitív hatásokat egyaránt megengedő értelmezéseik révén forgatókönyv-tengelyekké válhassanak. Minden résztvevő titkosan rangsorolt, és a legtöbbször említett két tengelyképzőt fogadtattuk el forgatókönyv-tengelynek az egyes csoportokban. A sok hatótényezöböl a választott vállalat szempontjából a két legfontosabb és egyben legbizonytalanabb jövőformálót kellett kiválasztani. A rangsorolásoknál az 1. csoport volt a legnehezebb helyzetben, mert a 92 hatótényező közül nehéz volt a választás úgy, hogy a csoport tagjai mindannyian elfogadják a kiválasztott tengelyeket. Nehezítette a tengelyválasztást annak a követelménynek a betartása is, hogy a tengelyek két különböző hatótényező csoportból kellett, hogy kikerüljenek, továbbá elvárás volt az is, hogy nagy hatást legyenek képesek gyakorolni a vállalat jövőjére akkor is, ha most még nem tünik fontosnak a hatásuk. (Vagyis a jövőben nagy hatású és nagy bizonytalanságú tényezők közül kell tengelyeket választani ahhoz, hogy a jelentől pregnánsan eltérő forgatókönyveket tudjunk kimunkálni.) Ekkor volt a legélesebb vita a csoportokon belül, és a facilitátoroknak kellett terelni a dialógus vonulatát, hogy valóban megértsék a csoportok a tengelyek speciális tulajdonságait, és ráérezzenek választásuk logikájára és annak fontosságára.

A tengelyválasztás a „Gépipari vállalat” csoportnál a technológiai fejlődésre és a képzett munkaerő rendelkezésre állására esett (1. ábra). A „Logisztikai központ a V4-ek régiójában“ csoport a fogyasztói elégedettség és az üzemanyagárak függvényébe helyezte el forgatókönyveit (2. ábra). A „3D-s Nyomtató Társaság“ csoport a technológia evolúciója és az árszintek változásának mértéke függvényében készítette el forgatókönyveit (3. ábra).

\section{A mikroszintre elkészített forgatókönyv-alternatívák}

A tengelyválasztás munkája után az egyes síknegyedek felrajzolása és azok megnevezése következett. Ekkor azt kellett átgondolniuk a csoporttagoknak, hogy a kétkét tengelyszakasz által bezárt síknegyedben az egyes hajtóerők milyen mértékben és formában határozhatják meg vállalatuk jövőbeni tulajdonságait. E tulajdonságok számbavétele tette lehetővé, hogy kiderítsék, melyik sík- negyedben milyen lesz az elképzelt vállalat profilja és az a profil mennyire jelenthetne kívánatos jövőt számukra. Ezt első körben csak a tengelyek, valamint a többi hajtóerő közül választott néhány hatótényező közötti logikai kapcsolatok megvilágításával tették meg, aminek révén rátaláltak az egyes síknegyedek rövid és találó elnevezésére. A tengelyválasztás és a négy lehetséges forgatókönyv elnevezése az egyes csoportoknál az alábbi formákat öltötte (lásd az 1., a 2. és a 3. ábrákat).

\section{1. ábra A „Gépipari Vállalat”}

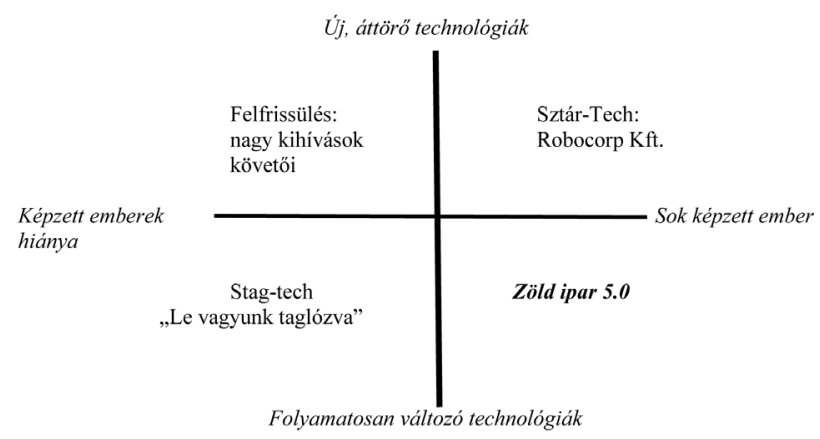

Forrás: Corporate Foresight Potential in Visegrad (V4) Countries (2016), 103. old. 13. ábrája alapján

Az idő rövidsége miatt a forgatókönyvírás teljes körü kidolgozása helyett csak egy, a csoport számára preferált forgatókönyv narratíváját kellett elkészíteni. Mindkét részfeladat csoportos vitát és döntéshozást igényelt. A preferált forgatókönyv-narratívák vázlatának elkészítése kapcsán az jelentett nehézséget, hogy a lehető legtöbb, már feltárt hatótényező feltételezett hatását figyelembe kellett venni. A facilitátorok segítségével, a viták mederben tartásával született meg az egyes csoportokban a kompromisszum a preferált vállalati jövőről és annak fontos tulajdonságairól.

\section{2. ábra A „Logisztikai központ a V4-ek régiójában”}

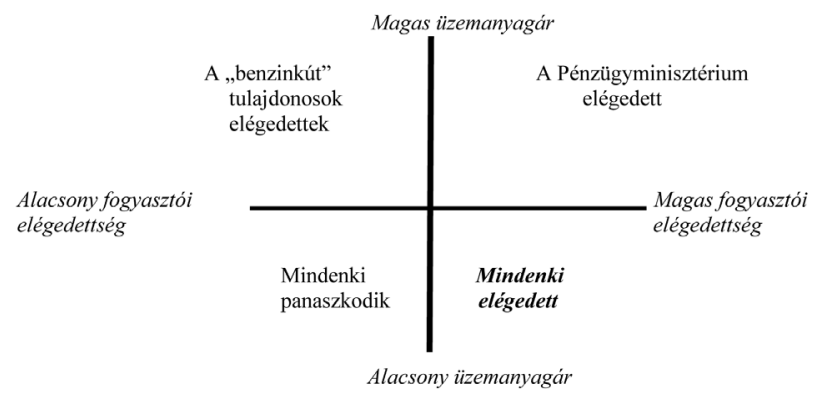

Forrás: Corporate Foresight Potential in Visegrad (V4) Countries (2016), 105. old. 14. ábrája alapján

Az ábrák alapján látható, hogy a technológia változása az 1. és a 3. csoport esetében (1. és 3. ábra) a legfontosabbnak bizonyult, így egyik tengellyé is vált. A másik tengely az 1. csoportnál (1. ábra) a szakemberek rendelkezésre állása, a 3. csoportnál (3. ábra) viszont a költségszint alakulása. A gépgyártó vállalatnál egyhangú választás eredményeképp technológia és szakember kell a gyártó cégek prosperáló jövőjéhez. A 3. vállalat esetében (3. ábra), ami- 
kor egy teljesen új technológia elterjesztése a tét, akkor a technológiai fejlődés átütő ereje mellett annak radikálisan olcsóbbá válása lehet az üzleti siker garanciája a résztvevők szerint. Itt a szakemberek rendelkezésre állása nem vált tengellyé, mert magától értetőnek vélték, hogy nélkülük a cég sem szoftvert nem tud fejleszteni, sem annak elterjesztését nem tudja elérni.

A 2. csoport Logisztikai központja (2. ábra) sajátos esetet képvisel, mert nem foglalkozik technológiákkal, azok rendelkezésre állását adottnak tekinti. Ugyanakkor bizonytalan és ezért rendkívül fontos az üzemanyagárak jövőbeni alakulása, és az, hogy a fogyasztók megelégedettek lesznek-e? Mindkét tengely gazdaságinak tünik, de az üzemanyagárak mögött természeti, technológiai, politikai stb. tényezőkomplexumok húzódnak meg. Úgyszintén a fogyasztói elégedettség sem csak gazdasági kategória, amit pl. az olcsó üzemanyagárak válthatnak ki, hanem e mögött is sokféle tényező áll, amelyek hatásai összegeződnek az elégedettségben. A kutatók véleménye szerint talán jobb lett volna, ha a csoport egyszerübb és mélyebben gyökerező tengelyeket választott volna, hiszen így nagyon nehézkesnek és kevésbé életszerünek tűnt a preferált alternatívájuk narratívája.

\section{3. ábra A „3D-s Nyomtató Társaság”}

Új, áttörố technológiák

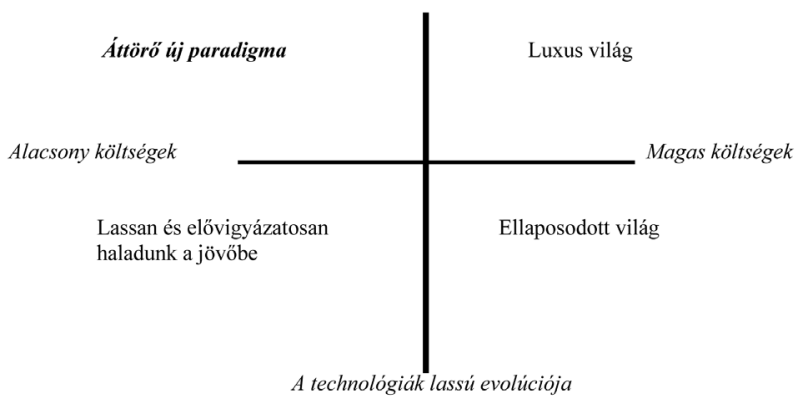

Forrás: Corporate Foresight Potential in Visegrad (V4) Countries (2016), 107. old. 15. ábrája alapján

A „Gépipari Vállalat” kívánatos jövőjét a Zöld ipar 5.0 változata képviselte. Az 1. csoport szerint az automatizációt jelentő 4.0 gyáripari jövő számukra azért kevés, mert a termelési-gyártási folyamatok nem odázhatják el az ökológiai problémák megoldását, a klímaváltozás elleni fellépést stb. Ezek ellen a gyártók csak eleve környezetkímélö, ökológiabarát technológiával tudnak tenni.

A „,3D-s Nyomtató Társaság“ kívánatos jövője is elsősorban technológiai függő, mert e téren paradigmaváltást látnak kívánatosnak a 3. csoport tagjai. Ez a paradigmaváltás azonban nem csak technológiai megújulás, hanem társadalmi igények, szabályok megújulása is. Pl. lesz-e igény hústáplálék vagy emberi szervek nyomtatására és az kielégíthető lesz-e elfogadható áron? A 3. csoport abban bízik, hogy a kezdeti 3D-s sikerek folytatódnak, és az egész gyártási folyamat meg fog újulni. Lehetővé válik majd a személyre szabott, otthoni, nyomtatott termékek előállítása. A hulladékkezelést és az újrahasznosítást is ezen új technológia mellett lesz célszerü keresni.

A „Logisztikai központ a V4-ek régiójában“ vállalat kívánatos jövője a legegyszerübb, mert a 2. csoport csak a mindenki boldog legyen kívánságot tudta megfogalmazni. Az ő narratívájukkal kapcsolatban merült fel a legtöbb kérdés, mert nem tünt életszerünek és elérhetőnek ez az általános elégedettség a logisztikai folyamatok terén, különösen regionális szinten.

\section{A mikroszintű kívánatos forgatókönyvek kapcsolata}

Az összesen 20 lehetséges forgatókönyv összekapcsolhatóságának vizsgálatától itt most eltekintünk, mert egyik forgatókönyv esetében sem került sor olyan részletekbe menő kidolgozásra, hogy ezt a kapcsolódást elemezni lehetne. Ennek egyik oka, hogy maga a mühelymunka sem nyújtott elég időt és lehetőséget arra, hogy a csoportonként 3-3 nem kívánatos forgatókönyvet is kidolgozzák az egyes csoportok, részletezve azok hátrányait és kockázatait. Ugyanakkor azt meg lehet tenni, hogy a kivánatos forgatókönyveket hozzuk kapcsolatba egymással. Ez az összekapcsolás viszont csak intuitív és logikai úton, az összeférhetőség és az összeférhetetlenség szintjén végezhető el.

A kívánatos forgatókönyvek bemutatása és megbeszélése révén nyert információk alapján a szakértő jövőkutatók és a vállalatvezetők arra a következtetésre jutottak, hogy jól illeszkedhetnek mind az 1., mind a 3. csoport preferált jövőalternatívái - a Zöld ipar 5.0 és a 3D-s nyomtatás -, mert új és globálisan is terjedő technológiákban keresnek maguknak speciális szerepkört, továbbá a régió szintjére is emelkedhet aktivitásuk. A Zöld ipar 5.0-ja azzal, hogy helyi példát kínálhat az ökológiabarát termelésre, amely exportcikké is válhat. A 3D-s nyomtatás maga is regionális, illetve globális szinten szeretne müködni egy meghatározott szerepkörben, a szoftver termelésére összpontosítva.

A 2. csoport logisztikai központja regionális hálózatként szervezné meg tevékenységét, tehát az általános elégedettségből minden V4-es ország részesülne. Ez a vállalkozás közvetlenül nem épülne új technológiákra, de azok nélkül nem tudna közmegelégedéssel és gazdaságilag hatékonyan müködni. A regionális logisztikai központ létrejöttének és fejlődésének viszont eleve feltétele a V4es országok erősödő kapcsolatrendszere. Ebből az látható, hogy a részt vevő vállalati szakemberek és jövőkutatók nagyon komolyan vették, hogy miként válhatnának a V4-ek egy erős, együttműködő, gyorsan korszerüsödő és fejlődő régióvá az EU-n belül. A forgatókönyvírás megtanulása során ezért felismerhetővé vált az a nem tudatos törekvés is, hogy az egyes vállalattípusok kívánatos jövöje mutasson túl egy-egy vállalkozási szféra fejlesztésében való érdekeltségen. Erre a vállalatvezetöi szándékra és 
törekvésre épitve regionális együttmüködéseket formáló forgatókönyvek is születhetnek. ${ }^{5}$

A forgatókönyvírás csoportos tanulása azt is megmutatta, hogy az eljárás a V4-es régióban történő továbbterjedése lehetővé tenné, hogy a jövőben különféle vállalattípusok és vállalkozói körök különbözö regionális jövőképeket eredményező forgatókönyveket is kidolgozhatnának, melyeket fejlesztési stratégiáik kimunkálására és régiós együttmüködések fejlesztésére használhatnának. Ezzel a szemléletmóddal bővíthető lehetne az a látókör, amely az üzleti lehetőségek érzékelését megkönnyítené. Ha ehhez még hozzákapcsolnánk a lehetséges, de nem kívánatos forgatókönyvek részletes kifejtését és elemzését, akkor a potenciális veszélyek érzékelésében és szem előtt tartásában is elöre léphetnénk.

\section{Következtetések, tapasztalatok}

A V4-es országokban az elöretekintés makro- és mezoszinten sokkal fejlettebb, mint mikro-, azaz vállalati szinten. A kutatásba bevont vállalatvezetők nyitottsága folytán rövid idő alatt sikeresen lehetett előrelépni az előretekintés vállalati kultúrájának fejlesztésében. Az érintettek részvételére alapozó forgatókönyvírás valóban aktivitásra és intenzív kommunikációra késztette a vállalatvezetőket, akik a workshop végére teljesen beleélték magukat a kívánatos jövőkbe és a jövőformálás kínálta döntési szituációba.

Az előretekintési folyamatban, noha nem vagyunk képesek megmondani sem a bekövetkezö, sem a kívánatos jövőt, viszont szisztematikusan fel tudunk tárni néhány jövőváltozatot, különösen akkor, ha a forgatókönyvírás módszerét következetesen alkalmazzuk. Ennek során le tudunk fektetni olyan kereteket, amelyek bepillantást ajánlanak ahhoz, hogy miként kell azonosítani, elemezni, megérteni, megvitatni, átformálni, összekapcsolni a változó trendeket, eseményeket, gyenge jeleket, hirtelen változásokat, várható előnyöket és veszélyeket stb., amelyek relevánsak lehetnek egy vállalat vagy vállalatcsoport számára problémáik (termékstratégia, $\mathrm{K}+\mathrm{F}$ politika, beruházási terv, biztonság stb.) közös feltárásában, kezelésében és jövőjük formálásában. Ezáltal a résztvevők gondolkodása ráirányítható a jövő különféle értelmezésére és felfogására, valamint a vállalatok közötti kapcsolatok erősítésére a jövő feltárásában és formálásában.

$\mathrm{Az}$ érintettek részvételével folyó forgatókönyvírás olyan eljárás, amely eleve a többféle jövőben való gondolkodást preferálja, és ahhoz ad egy szisztematikus és közösen tanulható sémát. Ez az eljárás kétdimenziós formájában a vállalatok számára akkor előnyös, ha az a vállalat képviselöi, az üzleti partnerek és további érintettek együttes részvételén alapul, és mind az előnyös, mind a hátrányos forgatókönyvek részletes feltárásával foglalkozik. A forgatókönyvírás mühelymunka keretében az érdekelt és az üzleti stratégia kialakításával foglalkozó szakemberek számára viszonylag könnyen és gyorsan volt tanítható és tanulható.

A jövőkutató facilitátor jelenléte és alkalmi segítsége mindenféle forgatókönyvírás folyamatában nélkülözhetetlen. Attól azonban tartózkodni kell, hogy a facilitátor befolyásolja az érintettek csoportos véleményformálását. A facilitátorok munkaszakaszonkénti helycseréje ezért jó megoldásnak bizonyult.

A vállalati és üzleti szintre koncentráló forgatókönyvírás - támaszkodva mind a külső, mind pedig a belső környezetből kiinduló hajtóerőkre - azt is érzékelhetővé tette, hogy a kívánatos forgatókönyvek kapcsán a alulról felfelé irányuló viszonylatokban rejlő főbb kapcsolódási pontokat is ki lehetett tapintani, s így váltak azok mind a kutatók, mind a gyakorlati szakemberek számára továbbgondolásra érdemessé.

\section{Felhasznált irodalom}

Alács, P. (2013). Micro-Meso-Macro: From the Heritage of the Oracle to Foresight. In Giaoutzi, M., \& Sapio, B. (Eds.), Recent development in Foresight methodologies (pp.109-121). London, UK: Springer.

Balogh Judit, \& Zimonyi Tünde (2006). Magyarország, mint logisztikai központ: Egy jövőkép megvalósitásának folyamata az elöretekintés módszerének tükrében (Szakdolgozat). Budapesti Corvinus Egyetem, Logisztika és Ellátási Lánc szakirány, Budapest, Magyarország.

Borch, K. (2013). The Role of Interaction in Foresight. In Borch, K., Dingli, S., \& Jorgensen, M. (Eds.), Participation and Interaction in Foresight (pp. 3-13). Cheltenham, UK: Elgar.

Borch, K., \& Mérida, F. (2013). Dialogue in Foresight: Consensus, Conflict and Negotiation. In Borch, K., Dingli, S., \& Jorgensen, M. (Eds.), Participation and Interaction in Foresight (pp. 97-117). Cheltenham, UK: Elgar.

Bradfield, R., Wright, G., Burt, G., Cairns, G., \& Van Der Heijden, K (2005). The Origins and Evolution of Scenario Techniques in Long Range Business Planning. Futures, 37, 795-812. DOI:10.1016/j.futures.2005.01.003

Corporate Foresight Potential in Visegrad (V4) Countries (2016). Sacio-Szymanska, A. (ed.) Radom. Elérhető: http://www.visegradforesight.itee.radom.pl/index.php/ $\mathrm{hu} /$

Daszkiewicz, N. (2014). Small and Medium-sized Enterprises in Visegrad Countries towards Internationalisation Challenges in the European Union. In Durendez, A., \& Wach, K. (Eds.) Patterns of Business Internationalisation in Visegrad Countries: In Search for

\footnotetext{
${ }^{5}$ A különböző, a mikro-, a mezo- és a makroszintek elöretekintési folyamatban történő szisztematikus összekapcsolásának még nem alakult ki a módszertana. Az ezzel kapcsolatos problémákat, elméleti és gyakorlati útkereséseket lásd Kok, Rothman \& Patel (2006), Kok, Rothman \& Pantel Qaranta (2006), Özkaynak \& Rodríguez-Labajos (2010) és Alács (2013) munkáiban. ${ }^{4}$ A csoportonkénti hajtóerők rövid felsorolását lásd Corporate Foresight Potential in Visegrad (V4) Countries (2016), 109-112. old.
} 
Regional Specifics. Universidad Politécnica de Cartagena, Cartagena. Elérhető: http://www.visegrad.uek. krakow.pl/PDF/Cartagena2014_ch09_daszkiewicz.pdf

Fahey, L., \& Randall, R. (Eds.) (1998). Learning from the Future: Competitive Foresight Scenarios. New York: Wiley.

Gáspár, J. (2015). A jövő alakitása a vállalati stratégiaalkotási gyakorlatban ( $\mathrm{PhD}$. disszertáció). Budapesti Corvinus Egyetem, Budapest, Magyarország. Elérhető: http://phd.lib.uni-corvinus.hu/889/2/Gaspar_Judit_den.pdf

Glann, J., \& Gordon, T. (Eds.) (2009). Futures Research Methodology. Version 3.0. Washington DC.: Millennium Project.

Godet, M. (2000). The Art of Scenarios and Strategic Planning: Tools and Pit6falls. Technological Forecasting and Social Change, 65, 3-22. DOI.org/10.1016/ S0040-1625(99)00120-1

Havas, A. (2003). Evolving Foresight in a Small Transition Economy. Journal of Forecasting, (22), 179-201. DOI. 10.1002/for.855

Hideg, É., Gáspár, J., Demus, T., Sugár, M., \& Tyukodi, G. (2017). A vállalati foresight helyzete Magyarországon. Vezetéstudomány, 48(6-7), 57-63. DOI: 10.14267/VEZTUD.2019.04.01

Hideg, É., \& Nováky, E. (2010). Changing Attitudes to the Future in Hungary. Futures, 42(3), 230-236. DOI:10.1016/j.futures.2009.11.008

Hideg, É., Nováky, E., \& Alács, P. (2014). Interactive Foresight on the Hungarian SMEs. Foresight, 16(4), 344359. DOI.org/10.1108/FS-12-2012-0091

Hideg, É., Nováky, E., \& Kristóf, T. (2013). Hungarian Educational Foresight: 'Vocational Training and Future'. In Borch, K., Dingli, S., \& Jørgensen, M.S. (Eds.), Participation and Interaction in Foresight. Dialogue, Dissemination and Visions (pp. 223-237). Northampton, MA: Edward Elgar Publishing.

Jannek, K., \& Burmeister, K (2007). Corporate Foresight in Small and Medium Sized Enterprises. The European Foresight Monitoring Network. Elérhető: http://www. foresight-platform.eu/wp-content/uploads/2011/04/ EFMN-Brief-No.-101-Corporate-Foresight-SME.pdf
Kanoniuk, A., \& Glinska, E. (2015): Foresight in a Small Enterprise. A Case Study. In Procedia: Social Behavioral Sciences. 20th International Scientific Conference Economics and Management 2015 (ICEM-2015), Vol. 213, 1., 971-976. Elérhető: http://science direct. com/science/article/pii/S1877042815058681

Kok, K., Rothman, D., \& Patel, M. (2006). Multi-Scale Narratives From an IA Perspective: Part I.and II. European and Mediterranean Scenario Development. Futures, 38 (3), 261- 284. DOI:10.1016/j.futures.2005.07.001

Kok, K., Rothman, D., Patel, M., \& Qaranta, G. (2006). Multi-Scale Narratives from an IA Perspective: Part II. Participatory Local Scenario Development. Futures, 38(3), 285-311. DOI.org/10.1016/j.futures.2005.07.006

Kristóf, T. (2013). Learning Theory in Foresight. In Borch, K., Dingli, S., \& Jorgensen, M. (Eds.), Participation and Interaction in Foresight (pp.70-96). Cheltenham, UK: Elgar.

Nemcová, E. (2013). Foresight as a Tool of Policy Formulation: The Slovak Foresight Excersice. In Borch, K., Dingli, S., \& Jorgensen, M. (Eds.), Participation and Interaction in Foresight (pp. 238-253). Cheltenham, UK: Elgar.

Özkaynak, B., \& Rodríguez-Labajos, B. (2010). MultiScale Interaction in Local Scenario-Building: A Methodological Framework. Futures, 42(9), 995-1006. DOI: 10.1016/j.futures.2010.08.022

Ringland, G. (2010): The Role of Scenarios in Strategic Foresight. Technological Forecasting and Social Change, 77(9), 1493-1498. DOI:10.1016/j.techfore.2010.06.010

Rohrbeck, R., Arnold, H., \& Heuer, J. (2007). Strategic Foresight: A Case Study on the Deutsche Telekom Laboraties. ISPIM - Asia Conference, New Delhi, India. Elérhető: https://papers.ssrn.com/sol3/papers. cfm?abstract_id=1896133

Valenta, O. (2014). National Priorities of Oriented Research. Development and Innovation in the Czech Republic. In Michalek, T., Hebáková, L., Hennen, L., Scherz, C., Nierling, L., \& Hahn, J. (Eds.) (2014), Technology Assessment and Policy Areas of Great Transitions. Proceedings from the PACITA Conference in Prague (pp. 107-115). Prague, Czech Republic. 